\title{
Geochemical Evidence for Earth's First Snowball Event
}

\author{
SOPHIE KURUCZ ${ }^{1}$, PHILIP FRALICK ${ }^{1 *}$ AND STEFAN \\ LALONDE $^{2}$ \\ ${ }^{1}$ Depart. of Geology, Lakehead Un., Thunder Bay, Canada, \\ skurucz@lakeheadu.ca,philip.fralick@lakeheadu.ca \\ ${ }^{2}$ CNRS-UMR6538 Geosciences Ocean, European Institute \\ for Marine Studies, Plouzane, France, \\ stefan.lalonde@univ.brest.fr
}

Ever since it was first proposed that the Earth completely froze during glaciations $\sim 640$ million years ago [1] evidence supporting this hypothesis has been increasing, primarily from samples of carbonates directly overlying glacial diamictites, termed cap carbonates. Carbon isotopes, Ba concentrations and REE patterns all indicate that these cap carbonates were deposited during worldwide deglaciation $[2,3]$. This was not the first extensive glacial period that affected planet Earth: $\sim 1750$ million years prior to Neoproterozoic glaciations the Earth went through its first major glacial episode, the Huronian glaciations. The second Huronian ice advance deposited the Bruce Formation, with its overlying cap carbonate, the Espanola Formation. This up to $\sim 300 \mathrm{~m}$ thick succession of limestone, siltstone, dolostone and sandstone has basal dropstone-bearing layers with $\delta^{13} \mathrm{C}_{\text {carb }}$ of $10 \%$, which transitions upwards over $200 \mathrm{~m}$ of section to $2.5 \%$. The basal ${ }^{12} \mathrm{C}$-enriched strata also have distinct REE patterns with negative Eu anomalies and extremely radiogenic $\mathrm{Sr}$ isotopes. These three observations are probably due to highly reducing conditions in the sediment, and the possible thawing of methane-rich areas, releasing fluids that mixed with the overlying bottom waters, plus the diagenetic incorporation of radiogenic $\mathrm{Sr}$ from abundant silty loess. The gradually increasing $\delta^{13} \mathrm{C}_{\text {carb }}$ was likely caused by progressive mixing of seawater with the freshwater plume, which initially extended to depths below wave base. Strata near the base of the cap carbonate have over $3000 \mathrm{ppm} \mathrm{Ba}$, possibly indicating an initial seawater influence. All of these observations are similar to Neoproterozoic cap carbonates, and provide new evidence for the possibly snowball Earth-like nature of the $\sim 2.4 \mathrm{Ga}$ Bruce glaciation.

[1] Kirschvink, J.L. (1992) in: The Proterozoic Biosphere, Cambridge Un. Press, 51-52. [2] Hoffman, P.F. and Schrag, D.P. (2002). Terra Nova 14:129-155. [3] Giddings, J.P. and Wallace, M.W. (2009). Sed. Geol. 216: 1-14. 